\title{
Molecular consequences of amyloid precursor protein and presenilin mutations causing autosomal-dominant Alzheimer's disease
}

Sascha Weggen ${ }^{1 *}$ and Dirk Beher*

\begin{abstract}
Mutations in both the amyloid precursor protein (APP) and the presenilin (PSEN) genes cause familial Alzheimer's disease (FAD) with autosomal dominant inheritance and early onset of disease. The clinical course and neuropathology of FAD and sporadic Alzheimer's disease are highly similar, and patients with FAD constitute a unique population in which to conduct treatment and, in particular, prevention trials with novel pharmaceutical entities. It is critical, therefore, to exactly define the molecular consequences of APP and PSEN FAD mutations. Both APP and PSEN mutations drive amyloidosis in FAD patients through changes in the brain metabolism of amyloid- $\beta$ (A $\beta$ ) peptides that promote the formation of pathogenic aggregates. APP mutations do not seem to impair the physiological functions of APP. In contrast, it has been proposed that PSEN mutations compromise $\gamma$-secretase-dependent and -independent functions of PSEN. However, PSEN mutations have mostly been studied in model systems that do not accurately reflect the genetic background in FAD patients. In this review, we discuss the reported cellular phenotypes of APP and PSEN mutations, the current understanding of their molecular mechanisms, the need to generate faithful models of PSEN mutations, and the potential bias of APP and PSEN mutations on therapeutic strategies that target $A \beta$.
\end{abstract}

*Correspondence: sweggen@uni-duesseldorf.de or dbeher@web.de 'Department of Neuropathology, Heinrich-Heine-University, Moorenstrasse 5, D-40225 Düsseldorf, Germany

${ }^{2}$ Global Research and Early Development, Merck Serono SA, 9 Chemin des Mines, 1202 Geneva, Switzerland

\section{Introduction}

Alzheimer's disease (AD) is the most common agerelated neurodegenerative disorder, currently affecting 20 to 30 million individuals worldwide [1]. The cardinal symptom of the disease is progressive memory loss due to the degeneration of neurons and synapses in the cerebral cortex and subcortical regions of the brain. Comprehensive evidence supports the amyloid hypothesis of AD, which argues that accumulation and aggregation of amyloid- $\beta(A \beta)$ peptides in the brain is causal in its pathogenesis. $A \beta$ is a proteolytic fragment generated through sequential cleavage of the amyloid precursor protein (APP) by $\beta$-secretase (BACE1) and $\gamma$-secretase. Cells produce $A \beta$ peptides of variable length. A peptide of 40 amino acids $(A \beta 40)$ is the most prevalent species secreted by cells, whereas the longer A $\beta 42$ isoform appears to be the key pathogenic species and the most abundant species deposited in the brain. Major support for the amyloid hypothesis is drawn from cases of earlyonset familial AD (FAD). As used in this review, the term FAD is confined to familial cases with an autosomaldominant inheritance pattern. Missense mutations that are causative of FAD have been identified in three genes that are essential for the generation of $A \beta$ peptides: the $A P P$ gene and two homologous genes that encode the catalytic subunit of $\gamma$-secretase, PSEN1 (encoding presenilin-1) and PSEN2 (encoding presenilin-2) [2,3]. Overall, the clinical presentation of FAD patients with APP and PSEN mutations is very similar to that of sporadic AD, which is supported by neuroimaging, biomarker and post-mortem neuropathology studies. Recently, the clinical findings in FAD mutation carriers have been summarized in an excellent review by Bateman and colleagues [4] and will not be further discussed here.

\section{Discovery of amyloid precursor protein mutations}

It is undisputable that since the first description of the pathology of AD by the German psychiatrist and neuropathologist Alois Alzheimer in 1906 to the early days of the amyloid cascade hypothesis, both modern biochemistry and genetics have played major roles in advancing 
our understanding of this neurodegenerative condition. With the knowledge of the $A \beta$ peptide sequence obtained from purified fractions of either vascular amyloid or senile plaques from $\mathrm{AD}$ and Down's syndrome patients, the identification of APP was a logical step forward [5-7]. Since the $A \beta$ peptide represents only a small fragment of APP including part of the transmembrane domain, it was apparent that its de novo generation required at least two proteolytic activities (Figure 1a). Particularly troublesome at the time was the second processing step in the transmembrane domain (TMD) since intramembranecleaving proteases were only discovered more than a decade later. Nevertheless, with the sequencing of the $A \beta$ peptide and the cloning of APP a lively scientific debate had begun on their causative association with $\mathrm{AD}$. In addition to $A \beta$ being the major constituent of two of the three hallmarks of $\mathrm{AD}$ - senile plaques and vascular amyloid - the chromosomal location of APP also strongly argued in favor of a crucial role for it. The APP gene is located on chromosome 21, which had been linked to $\mathrm{AD}$ by multiple genetic linkage studies and the observation that Down's syndrome patients develop dementia accompanied by prototypical neuropathological hallmarks of $\mathrm{AD}[8,9]$. Three years after the cloning of APP, the E693Q Dutch missense mutation in the mid-region of $A \beta$ (E22Q when referring to the $A \beta$ peptide sequence) was identified as being causative of hereditary cerebral hemorrhage with amyloidosis Dutch-type (HCHWA-D) (Figure 1b) [10]. Although the neuropathology of HCHWA-D is clearly distinct from that of $\mathrm{AD}$, this milestone discovery provided the first evidence that the APP gene harbors autosomal-dominant mutations causing dementia. HCHWA-D itself is characterized by severe vascular amyloid deposition, termed cerebrovascular amyloid angiopathy (CAA), in addition to parenchymal plaques. $\mathrm{CAA}$ as a result of targeting $\mathrm{A} \beta$ deposition to blood vessels ultimately leads to cerebral hemorrhages and strokes. One year later, the $\mathrm{AD}$ community received the long awaited news regarding the discovery of several causative FAD mutations in APP. These were located at the V717 position and included the London (V717I) [11], Indiana (V717F) [12] and V717G [13] mutations. These major discoveries spurred the identification of a continuous stream of additional CAA and FAD mutations to the present time (highlighted in Figure $1 \mathrm{~b}$ and Table 1). The detailed investigation of their biological phenotypes relied, to a large extent, on progress in the understanding of the physiological metabolism of APP and further advancements in assay technologies, such as highly sensitive immunoassays capable of discriminating $A \beta 40$ and $A \beta 42$ peptides. In this respect, the observation that $A \beta$ peptide secretion is the result of a physiological process not only pointed towards the existence of cellular proteases capable of APP processing but also provided an
Table 1. Primary references of amyloid precursor protein mutations

\begin{tabular}{|c|c|c|c|c|}
\hline Mutation $^{a}$ & Phenotype & $\begin{array}{l}\text { Common } \\
\text { name }\end{array}$ & $\begin{array}{c}\text { Publication } \\
\text { date }\end{array}$ & Reference \\
\hline KM670/671N & $N L \quad A D$ & Swedish & 1992 & [38] \\
\hline A673V & $\mathrm{AD}$ (recessive) & & 2009 & [105] \\
\hline H677R & $A D$ & & 2003 & [106] \\
\hline D678N & $A D$ & & 2004 & [107] \\
\hline A692G & $C A A^{b}$ & Flemish & 1992 & [108] \\
\hline E693Q & HCHWA-D & Dutch & 1990 & [10] \\
\hline E693G & $A D$ & Arctic & 2001 & {$[26]$} \\
\hline E693K & CAA & Italian & 2010 & [109] \\
\hline $\mathrm{E} 693 \triangle$ & $A D$ & Osaka & 2008 & {$[27]$} \\
\hline D694N & $A D$ and $C A A$ & lowa & 2001 & [110] \\
\hline A713T & $\mathrm{AD}$ and $\mathrm{CAA}$ & & 2004 & [111] \\
\hline $\mathrm{T} 7141$ & $A D$ & Austrian & 2000 & [112] \\
\hline $\mathrm{T} 714 \mathrm{~A}$ & $A D$ & Iranian & 2002 & [113] \\
\hline V715M & $A D$ & French & 1999 & [114] \\
\hline V715A & $A D$ & German & 2001 & [115] \\
\hline I716V & $A D$ & Florida & 1997 & [116] \\
\hline I716F & $A D$ & & 2010 & [117] \\
\hline V717I & $A D$ & London & 1991 & [11] \\
\hline V717F & $A D$ & Indiana & 1991 & [12] \\
\hline V717G & $A D$ & & 1991 & [13] \\
\hline V717L & $A D$ & & 2000 & [118] \\
\hline T719P & $A D$ & & 2009 & [119] \\
\hline L723P & $A D$ & Australian & 2000 & [120] \\
\hline $\mathrm{K} 724 \mathrm{~N}$ & Likely AD & & 2006 & [121] \\
\hline
\end{tabular}

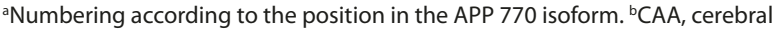
amyloid angiophathy; HCHWA-D, hereditary cerebral hemorrhage with amyloidosis Dutch-type (for a continuously updated list of APP mutations, see [55]). AD, Alzheimer's disease; APP, amyloid precursor protein.

in vitro system for studying mutant APP variants in detail [14].

\section{Amyloid precursor mutations causative of cerebrovascular amyloid angiopathy}

When comparing the APP FAD and CAA mutations it is evident that these cluster around hot spots in the APP protein sequence (Figure 1a). The mutations causative of CAA are located in the central region of the peptide. At the molecular level, these mutations change the charge distribution and thereby likely affect the peptide structure, ultimately promoting fibril formation $[15,16]$. Most data to date have been generated for the E22Q (E693Q) Dutch peptide. Limited proteolysis and NMR has identified a turn in the V24-K28 region, which appears to be critical for folding of the monomer and is stabilized, in part, by electrostatic interactions between 


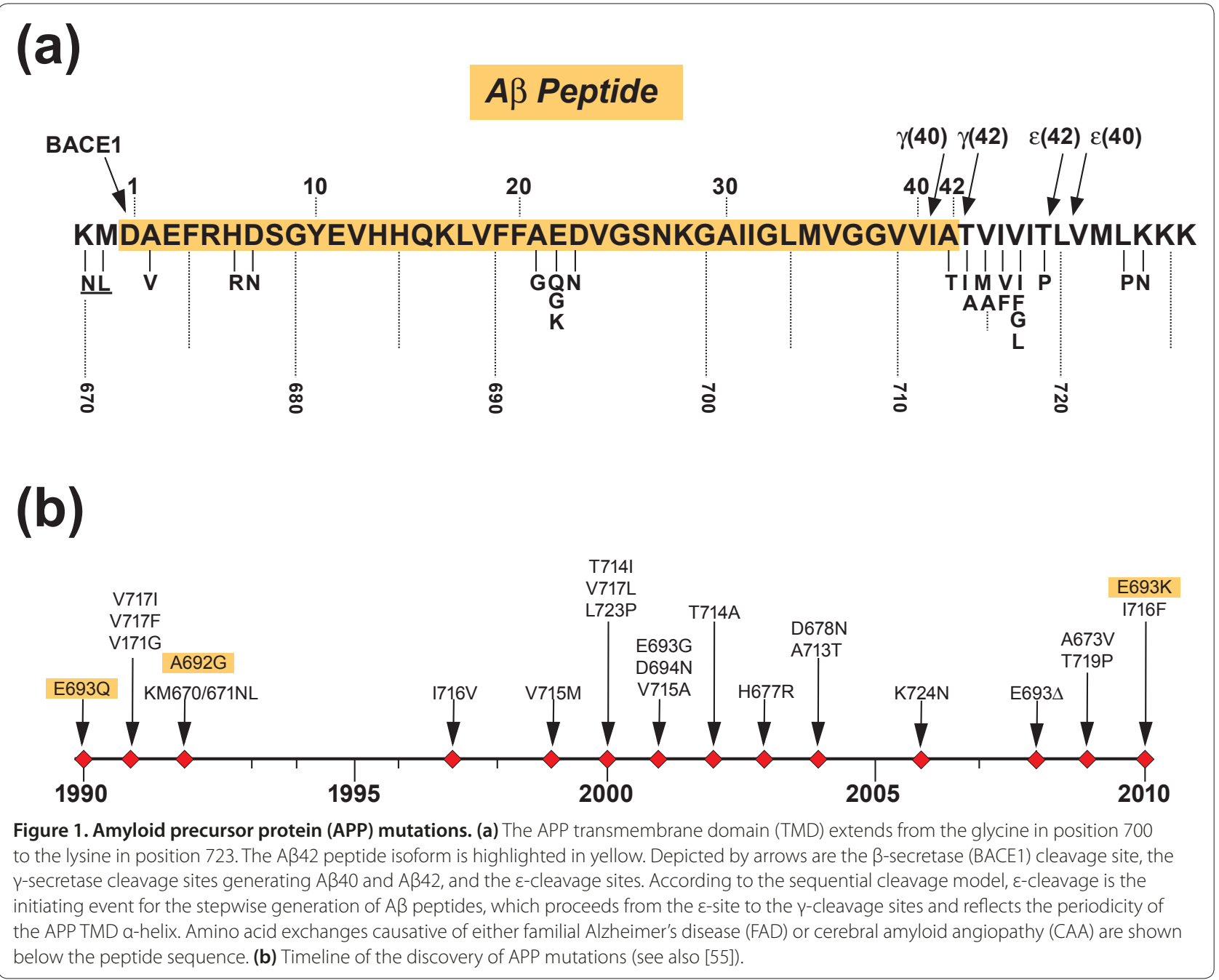

E22 and K28. E22 and D23 mutations destabilize this turn and thereby promote oligomer formation $[17,18]$. Accordingly, in biological systems, increased toxicity in human leptomeningeal smooth muscle cells and enhanced neurotoxicity have been reported for the Dutch peptide $[19,20]$. This peptide also appears to be less efficiently degraded by the prototypical A $\beta$-degrading enzyme insulin-degrading enzyme [21]. Transgenic animal models expressing Dutch APP recapitulate the human pathology, with the vasculature being the main site of amyloid deposition [22]. With respect to $A \beta$ production itself, no coherent phenotype has been observed for the CAA mutants. The A692G Flemish mutation enhances $A \beta 40$ and $A \beta 42$ production whereas the Dutch mutation does not appear to affect $A \beta$ production at all [23]. The enhanced $A \beta$ production of the Flemish mutation was reported in 1994 [24]. Many years later, a systematic analysis of the domain surrounding A692 has identified a substrate inhibitory domain (ASID) in APP [25]. This domain appears to exert a negative control over the activity of $\gamma$-secretase. Intriguingly, only the A692G amino acid exchange introduced by the Flemish mutation, but none of the other CAA/FADassociated mutations in the ASID domain, lowered its inhibitory potency, thus raising $\mathrm{A} \beta$ production [25]. This adds another facet to the mechanistic understanding of the Flemish CAA mutation. It is reasonable to assume, however, that the main driver for the CAA pathology is the change of the $A \beta$ peptide sequence itself, since increasing total $A \beta$ production will lead to FAD and not CAA, as shown for the APP Swedish mutation (see below).

It is important to note that not all mutations in the central region of $A \beta$ cause $C A A$, as highlighted by the E693G Arctic and the E693 $\triangle$ FAD mutations [26,27]. Despite changing the sequence at exactly the same position affected by the Dutch and Italian CAA mutations, the Arctic mutation causes FAD characterized by the abundance of parenchymal plaques. However, these deposits are mainly ring-like in shape and devoid of a 
dense core [28]. In good agreement with the human pathology, transgenic mouse models overexpressing Artic APP show fast and extensive parenchymal plaque formation and lack the profound vascular pathology observed in Dutch APP-overexpressing mice [29]. Conflicting data have been published for the APP E693 FAD mutation. This mutation was initially reported to promote the formation of toxic oligomers, and APP E693 $\Delta$ transgenic mice lack extensive amyloid deposition $[27,30]$. In contrast, more recent biophysical studies have shown that the mutant peptide forms amyloid fibrils extremely rapidly [31-33].

Taken together, this leaves some important questions unanswered, such as why CAA mutations specifically target $A \beta$ deposition to the brain capillaries. One common hypothesis is that the aggregation kinetics of the CAA peptides reduce their clearance across the blood-brain barrier [22]. A major contributor could be the specific cellular environment in the vasculature since smooth muscle cell surfaces in particular have been shown to promote CAA A $\beta$ aggregation [34].

\section{Amyloid precursor protein mutations causative of familial Alzheimer's disease}

In retrospect it is not surprising that almost all APP mutations causative of FAD cluster around the sites of proteolytic processing by the $\beta$-secretase and $\gamma$-secretase enzymes, releasing the $\mathrm{A} \beta$ peptides into the luminal/ extracellular compartment. A seminal observation came from the analysis of the KM670/671NL Swedish APP mutation, which reproducibly increased total A $\beta$ secretion in both Swedish APP transfected cells and skin fibroblasts from carriers of the mutation [35-38]. Mechanistically, this mutant is well understood, converting the APP sequence into a better substrate for BACE1, which became apparent after the enzyme had been cloned $[39,40]$. This increase in substrate affinity not only raises $\mathrm{A} \beta$ production but also influences the cellular compartment where the cleavage takes place. Whereas BACE1 processing of wild-type (WT) APP requires trafficking to the cell surface and recycling into early endosomes [41], evidence from non-neuronal cell lines suggests that Swedish APP may already be processed in the transGolgi network compartment [42]. Both of these unique features of Swedish APP have therapeutic implications. Since all BACE1 inhibitors currently entering clinical development target the active site, these can be presumed to be competitive with the substrate. This has consequences for their pharmacology and compound affinities are reduced in Swedish APP-expressing systems [43]. Consequently, BACE1 inhibitor drugs could be less efficient at inhibiting BACE1 in Swedish APP mutation carriers. In addition, if antibodies inhibiting BACE1 were to be moved into the clinic, it is unlikely that these would reach the early intracellular compartments where Swedish APP is cleaved. This was supported by a recent study demonstrating that, in contrast to the situation in WT animals, BACE1 antibodies were incapable of inhibiting the enzyme in a Swedish APP transgenic mouse model [44].

The remaining FAD mutations tend to accumulate distal to the $\gamma$-secretase cleavage site. Mechanistically, most of them elevate the $A \beta 42 / A \beta 40$ ratio (Table 2), with the most robust data being obtained for the V717 FAD mutants [45-47]. This strongly supported a causative role of the longer $A \beta 42$ peptide, which in animal models appeared to be essential for senile plaque formation [48]. However, the discovery of the $\varepsilon$-cleavage [49], which leads to the release of the APP intracellular domain (AICD), suggested that aberrant APP/AICD signaling might provide an alternative explanation of how APP FAD mutations cause AD. The $\varepsilon$-cleavage is homologous to the S3 cleavage in the Notch receptor and occurs in proximity to the cytosolic face of the membrane. It is also mediated by $\gamma$-secretase and liberates an intracellular domain capable of recruiting accessory proteins, which in turn could modulate nuclear gene expression [2]. When AICD generation from FAD mutants was quantified, conflicting data were obtained depending on the assay used (Table 2). Using a luciferase reporter assay in cells essentially reflecting AICD detachment from the membrane and translocation to the nucleus, several APP FAD mutants did not show any differences compared to the WT APP [45]. When AICD generation in membranes was quantified by western blot immunodetection, some mutations (for example, T714I) showed reduced and some increased (for example, I716V) AICD production, whereas all FAD mutants increased the A $\beta 42 / A \beta 40$ ratio [46]. Overall, despite some experimental differences, no coherent pattern has been reported for AICD generation and APP mutations. It is not likely, therefore, that disturbed APP/AICD signaling contributes to FAD.

The key question of how exactly these FAD mutations promote the elevation of the $A \beta 42 / A \beta 40$ ratio still remains unresolved. The answer may lie in the way $\gamma$-secretase cleaves its substrates. $\gamma$-Secretase cleaves at multiple sites within the APP TMD, and various A $\beta$ peptide species have been identified in cell supernatants $(\mathrm{A} \beta 33,34,37,38,39,40,42,43)$ and cell lysates $(\mathrm{A} \beta 45$, $46,48,49)$. Recent data suggest a stepwise mode of cleavage with initiation at the $\varepsilon$-cleavage site $[2,50]$. This initial processing event is followed by successive tripeptide generation, which proceeds from the $\varepsilon$-cleavage site to the $\gamma$-cleavage sites and reflects the periodicity of the $\alpha$-helix. According to this model, the initiation site for $\mathrm{A} \beta 42$ and $\mathrm{A} \beta 40$ would be at positions 48 (APP T719) and 49 (APP L720), respectively, in the A $\beta$ domain. An increase in the efficiency to initiate the $A \beta 42$ lineage of 
Table 2. Phenotypes of common amyloid precursor protein mutations

\begin{tabular}{|c|c|c|c|c|}
\hline APP mutation & $A \beta$ generation & AICD generation & AICD/ع-cleavage quantification & Reference \\
\hline KM670/671NL (Swedish) & $\begin{array}{l}\text { Total } A \beta \uparrow \text { in transfected cells } \\
\text { (6-to } 8 \text {-fold) and human FAD } \\
\text { fibroblasts (3-fold) }\end{array}$ & ND & ND & {$[35-37]$} \\
\hline Various 717 & $\mathrm{~A} \beta 42 \uparrow(1.5$ - to 1.9 -fold $)$ & ND & ND & {$[47]$} \\
\hline $\begin{array}{l}\text { T714I, V715M, I716F, V717I, } \\
\text { V717F, V717G }\end{array}$ & $\mathrm{A} \beta 42 / 40 \uparrow$ for $V 717 \mathrm{l}$, others ND & $\mathrm{AICD} \rightarrow$ & C99 luciferase reporter & {$[45]$} \\
\hline $\begin{array}{l}\text { T714I, V715M, I716V, V717I, } \\
\text { V717L, L723P }\end{array}$ & All mutants $A \beta 42 / A \beta 40 \uparrow$ & $\begin{array}{l}\text { T714l: AICD } \downarrow \\
\text { L723P: AICD } \downarrow \\
\text { V715M: AICD } \uparrow \\
\text { I716V: AICD } \uparrow \\
\text { V717l : AICD } \rightarrow \\
\text { V717L: AICD } \rightarrow\end{array}$ & $\begin{array}{l}\text { Immunodetection of AICD after in vitro } \\
\text { generation in membranes (APP Swedish } \\
\text { combined with second mutant) }\end{array}$ & {$[46]$} \\
\hline $\mathrm{T} 7141$ & $A \beta 42 / A \beta 40 \uparrow(11$-fold $)$ & ND & ND & [113] \\
\hline V715F & $\begin{array}{l}A \beta 40 \text { and } A \beta 42 \downarrow \\
A \beta 38 \uparrow\end{array}$ & $\mathrm{AlCD} \rightarrow$ & $\begin{array}{l}\text { Immunodetection of AICD after in vitro } \\
\text { generation in membranes }\end{array}$ & [123] \\
\hline E693Q Dutch & $\mathrm{A} \beta \rightarrow$ & ND & ND & [23] \\
\hline A692G Flemish & $A \beta 40$ and $A \beta 42 \uparrow$ & ND & ND & {$[23,24]$} \\
\hline E693G Arctic & $A \beta 42 \downarrow$ & ND & ND & [26] \\
\hline A673V (recessive) & $\begin{array}{l}A \beta 40 \text { and } A \beta 42 \uparrow \\
\text { Aggregation and fibril formation } \uparrow \\
\text { in homozygous carriers, but anti- } \\
\text { amyloidogenic in heterozygous }\end{array}$ & ND & ND & [105] \\
\hline
\end{tabular}

Note that immunoassays discriminating $A \beta 40$ and $A \beta 42$ became available in 1994 [46] and any prior data are based on immunoprecipitation of ${ }^{35} S$-methionine labeled total $A \beta$. $\varepsilon$-Cleavage leading to AICD formation was discovered in 2001 [48]. Up arrows indicate increase; down arrows indicate decrease; right-pointing arrows indicate no change compared to WT APP. A $\beta$, amyloid- $\beta$; AICD, amyloid precursor protein intracellular domain; APP, amyloid precursor protein; ND not determined.

peptides at T719 or in turn a decrease at initiating the A 340 lineage at L720 would lead to an elevation of the $\mathrm{A} \beta 42 / \mathrm{A} \beta 40$ ratio. In this respect, the region comprising residues T714 to V717 must harbor critical structural determinants governing enzyme binding and positioning for lineage initiation [51]. Mechanistically, one could view these mutations as quasi loss-of-function variants. If the enzyme had evolved to efficiently convert the APP substrate into $A \beta 40$, any mutation forcing the enzyme towards the less efficient A $\beta 42$ lineage would fit this definition.

\section{Presenilin mutations}

The vast majority of FAD cases harbor heterozygous mutations in the PSEN1 gene on chromosome 14. Sherrington and colleagues [52] identified the first mutations in PSEN1 in 1995. In the same year, mutations in the homologous gene PSEN2, on chromosome 1, were described [53,54]. Since then, more than 180 different pathogenic mutations in more than 400 families have been identified in PSEN1 and an additional 13 mutations in PSEN2 (see the Alzheimer Disease and Frontotemporal Dementia Mutation Database $[55,56]$ for a complete list of mutations). Individuals with PSEN1 mutations typically become symptomatic between the ages of 30 and 50 years.

\section{Y-Secretase-dependent and -independent functions of presenilin proteins}

PSEN proteins have been proposed to exert both $\gamma$-secretase-dependent and -independent functions. While it is far beyond the scope of this review to discuss all known physiological functions of PSEN proteins, we will briefly summarize PSEN activities that might be impaired by FAD mutations.

PSEN proteins form the catalytic core of $\gamma$-secretase, a multi-subunit aspartyl protease that catalyzes the last step in the generation of the $A \beta$ peptides from its substrate APP [2]. PSEN proteins have a nine TMD topology, and two critical aspartate residues in TMD6 and TMD7 form the active center of $\gamma$-secretase. PSEN proteins are incorporated together with three accessory proteins, nicastrin, APH-1 (anterior pharynx defective-1), and PEN-2 (presenilin enhancer-2), into high molecular weight complexes. In addition to APP, more than 90 type-I transmembrane proteins have been identified as substrates of $\gamma$-secretase. The most prominent substrate aside from APP is the NOTCH receptor. Processing of 
$\mathrm{NOTCH}$ by $\gamma$-secretase liberates the $\mathrm{NOTCH}$ intracellular domain (NICD), which translocates into the nucleus and regulates transcription of target genes involved in cell fate decisions during embryogenesis and adulthood. Abrogation of NOTCH receptor processing and signaling causes dramatic phenotypes in a variety of organisms [2]. Another example is the proteolytic processing of the transmembrane receptors ErbB4 and DCC (deleted in colorectal cancer) by $\gamma$-secretase, which appears to be required for important neurodevelopmental processes such as axon guidance and astrogenesis $[57,58]$. However, the physiological significance of $\gamma$-secretasemediated cleavage events in most of the other substrates remains to be clarified.

PSEN proteins may also have important $\gamma$-secretaseindependent functions. These include the modulation of specific signal transduction pathways, a critical function in lysosomal proteolysis and autophagy, and the regulation of the cellular calcium homeostasis [2,59-62].

\section{Current models of FAD-associated presenilin mutations}

It is generally accepted that the effects of APP mutations on $A \beta$ generation and aggregation can be accurately modeled by overexpression of mutant APP in cultured cells or transgenic mice; however, this is less evident for PSEN mutations. Overexpression of PSEN does not increase $\gamma$-secretase activity or production of $A \beta$ peptides by itself. Instead, ectopic expression of PSEN leads to incorporation of exogenous PSEN molecules into the complex in exchange for endogenously expressed PSEN [63]. This replacement phenomenon demonstrates that the active $\gamma$-secretase complex contains all four subunits in a definite stoichiometry, and that the abundance of the accessory proteins is limiting for the formation of mature and enzymatically active complexes [2]. In most studies, FAD PSEN mutants have been stably overexpressed in permanent cell lines or transgenic mice, leading to replacement of endogenous WT PSEN1 and PSEN2 proteins in cellular $\gamma$-secretase complexes [63]. Alternatively, PSEN mutants were expressed in PSEN1/PSEN2-/double-knockout cell lines that do not harbor endogenous WT PSEN proteins $[64,65]$. Accordingly, it is expected that functional $\gamma$-secretase complexes in both of these tissue culture models contain predominantly or solely the exogenously expressed PSEN mutants (Figure 2). However, this situation is strikingly different from FAD patients with heterozygous PSEN1 (or PSEN2) mutations who express mutant and WT PSEN1 (or PSEN2) in an approximately equal ratio in the background of two WT PSEN2 (or PSEN1) alleles (Figure 2). In addition, a small number of knock-in mouse strains for FAD PSEN1 mutations have been created, in which the mutant alleles are expressed under control of the endogenous mouse PSEN1 promoter, and few studies have investigated the impact of the mutant alleles on $A \beta$ production, processing of other $\gamma$-secretase substrates, and $\gamma$-secretase-independent functions of PSEN [66-69]. Finally, some studies have used primary cells from FAD patients to confirm proposed effects of PSEN mutants [70]. Nevertheless, it follows that the vast majority of investigations have been conducted in model systems that seem appropriate to assess the effects of isolated mutant alleles but that do not accurately reflect the genetic background in FAD patients with PSEN mutations.

\section{Presenilin mutations: loss-of-function, gain-of- function, or both?}

A vigorous debate has been initiated over the issue of whether FAD PSEN alleles represent loss-of-function or gain-of-function mutations. The arguments in this debate range from the proposition that alterations in the $A \beta 42 /$ A $\beta 40$ ratio are the only meaningful outcome of PSEN mutations to the hypothesis that $\mathrm{AD}$ is unrelated to changes in $A \beta$ production and is primarily caused by a loss of various PSEN protein functions [71-73]. $\gamma$-Secretasedependent phenotypes of specific PSEN mutations that have been investigated in multiple independent studies or model systems are summarized in Table 3.

Initially, measurements of steady-state $A \beta$ levels in transfected cells, transgenic mice and primary cells of FAD patients with PSEN1 or PSEN2 mutations suggested that the common pathogenic mechanism of PSEN mutations was to selectively elevate the absolute amount of cellular A $\beta 42$ production, which was interpreted as a gain-of-toxic function mechanism [70,74]. However, subsequent experiments have demonstrated that many FAD PSEN mutations when overexpressed display reduced overall $\gamma$-secretase activity compared to WT PSEN proteins. This was first recognized by Song and colleagues, who showed that overexpression of the PSEN1 mutations C410Y and G384A in PSEN1-/- knockout cells resulted in reduced NICD production [75]. These findings correlated closely with results from in vivo experiments in PSEN-deficient Caenorhabditis elegans and Drosophila that reported a complete rescue of NOTCH phenotypes after transgenic expression of human WT PSEN1 but only partial rescue with FAD PSEN1 mutants [76,77].

Since then several studies have confirmed that many PSEN1/PSEN2 mutations cause reduced NOTCH cleavage, decreased formation of the AICD fragment, and reduced processing of other $\gamma$-secretase substrates such as N-cadherin $[64,65,78-81]$. Studies have further shown that elevations in the $A \beta 42 / A \beta 40$ ratio after expression of some PSEN mutations are, to a large degree, due to reduced $A \beta 40$ levels and not to increases in the absolute amounts of $\mathrm{A} \beta 42$ peptides $[64,65,69,80$, 82-84]. In the majority of these studies, PSEN mutations 


\section{Tissue culture models}

Wild type PSEN1/PSEN2 cells

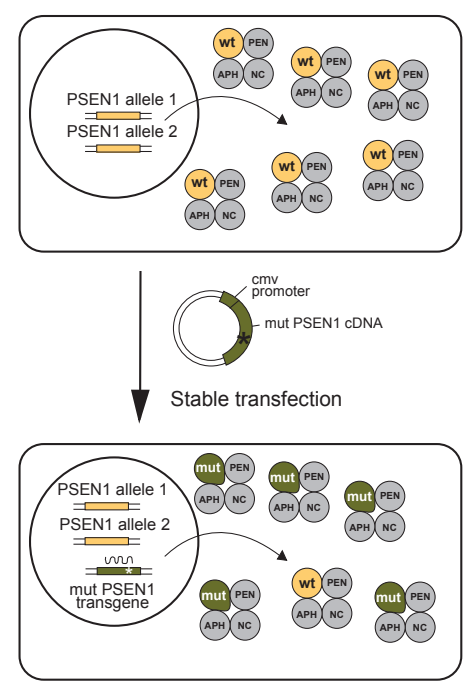

$\gamma$-secretase complexes

almost $100 \%$ mutant
PSEN1/PSEN2 knockout cells
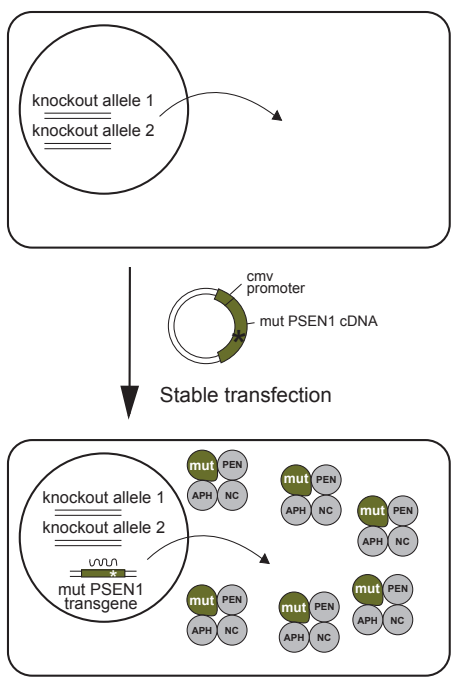

$\gamma$-secretase complexes $100 \%$ mutant
FAD PSEN1 patient

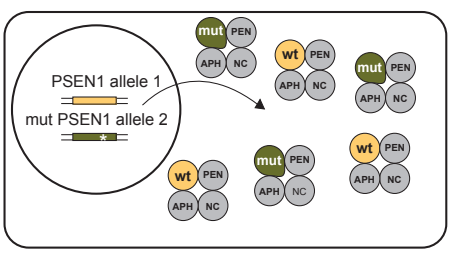

$\gamma$-secretase complexes

$50 \%$ wild type

$50 \%$ mutant

Figure 2. Tissue culture models of presenilin (PSEN) mutations. In most studies, PSEN mutants have been stably overexpressed either in permanent cells lines (left) or in PSEN1/PSEN2-/- double-knockout cell lines (middle). Due to the replacement phenomenon or the lack of endogenous wild type (WT) PSEN proteins, functional $y$-secretase complexes in both of these tissue culture models contain predominantly or solely the exogenously expressed PSEN mutants. This situation is different from familial Alzheimer's disease (FAD) patients with heterozygous PSEN1 (or PSEN2) mutations that express mutant and WT PSEN1 (or PSEN2) in an equal ratio in the background of two WT PSEN2 (or PSEN1) alleles (right). CMV, cytomegalovirus.

were stably or transiently overexpressed in either permanent cell lines with endogenous PSEN expression or in fibroblasts derived from PSEN1/PSEN2-/- knockout mice, and steady-state levels of $A \beta$ peptides and $\gamma$-secretase cleavage product were measured in cell culture supernatants or lysates. With regard to $A \beta$, these steadystate measurements represent the net effect of production, degradation, secretion and cellular uptake. In addition, kinetic studies of PSEN mutants have been performed in cell-free assays, which use solubilized membrane preparations from cells expressing PSEN mutants and employ exogenously added recombinant APP carboxyterminal fragments (CTFs) as substrates. These assays have confirmed that the rate of production of $A \beta$ peptides and the AICD domain over time is reduced for some PSEN mutants compared to WT PSEN [69,82-84]. The one consistent feature of PSEN mutations in all of these studies is that they increase the $A \beta 42 / A \beta 40$ ratio. For the wellstudied PSEN mutations listed in Table 2, this change in the $A \beta 42 / A \beta 40$ ratio can be due to an increase in $A \beta 42$ levels with unchanged A $\beta 40$ (PSEN1-M146L), increased A $\beta 42$ with decreased A 340 (PSEN2-N141I), unchanged
A 342 with decreased A $\beta 40$ (PSEN1-I213T), or a decrease in both $A \beta 42$ and $A \beta 40$ (PSEN1-C410Y). In addition, the mutants impair AICD and NICD generation and processing of other $\gamma$-secretase substrates like $\mathrm{N}$ cadherin to variable degrees. PSEN mutants that lower A 340 levels, such as PSEN1-L166P and PSEN2-N141I, tend to impair AICD and NICD generation, indicating a more severe loss of $\gamma$-secretase enzyme activity. In contrast, mutants that preserve A $\beta 40$ levels, such as PSEN1-M146L and PSEN1-A246E, also appear to preserve AICD and NICD levels, which is reflected in the ability of the PSEN1-A246E mutation to fully rescue the lethal phenotype of PSEN1-/- knockout mice $[85,86]$. Overall, results from cell-based models with overexpression of PSEN mutants and of kinetic studies in cell-free assays have been reasonably consistent in demonstrating a gradual loss of $\gamma$-secretase activity with the effect size depending on the specific PSEN mutation (Table 3). How can an overall decrease in $\gamma$-secretase activity caused by PSEN mutations explain the observed increase in the A $\beta 42 / A \beta 40$ ratio? According to the sequential cleavage model of $A \beta$ generation, $\gamma$-secretase cleavage takes place 
Table 3. $\mathrm{Y}$-Secretase-dependent phenotypes of presenilin mutations

\begin{tabular}{|c|c|c|c|c|c|c|c|c|}
\hline Model system & $A \beta 40$ & $A \beta 42$ & $A \beta 42 / A \beta 40$ & AICD & NICD & $\mathrm{N}$-cadherin & $\begin{array}{c}\text { Other } \\
\text { phenotypes }\end{array}$ & Reference \\
\hline \multicolumn{9}{|l|}{ PSEN1-M146L } \\
\hline Overexpression (HEK293, CHO) & $\rightarrow$ & $\uparrow$ & $\uparrow$ & ND & ND & $\downarrow$ & - & {$[79,80,83]$} \\
\hline Overexpression (PSEN-/-) & ND & ND & ND & ND & $\rightarrow$ & ND & - & [81] \\
\hline Kinetic in vitro assay & $\rightarrow$ & $\uparrow$ & $\uparrow$ & ND & ND & ND & - & [83] \\
\hline Transgenic mice & ND & $\uparrow$ & $\uparrow$ & ND & ND & ND & Total $A \beta \rightarrow$ & {$[74]$} \\
\hline \multicolumn{9}{|l|}{ PSEN1-L166P } \\
\hline Overexpression (HEK293) & $\downarrow$ & $\uparrow$ & $\uparrow$ & $\downarrow$ & $\downarrow$ & ND & - & {$[80]$} \\
\hline Overexpression (PSEN-/-) & $\downarrow$ & $\rightarrow$ & $\uparrow$ & $\downarrow$ & $\downarrow$ & $\downarrow$ & APP-CTFs $\uparrow$ & {$[64]$} \\
\hline \multicolumn{9}{|l|}{ PSEN1-I213T } \\
\hline Overexpression (PSEN-/-) & $\downarrow$ & $\downarrow$ & $\uparrow$ & ND & ND & ND & APP-CTFs $\rightarrow$ & [123] \\
\hline Kinetic in vitro assay & $\downarrow$ & $\rightarrow$ & $\uparrow$ & ND & ND & ND & - & {$[84]$} \\
\hline Knock-in mice (heterozygous) & $\rightarrow$ & $\uparrow$ & $\uparrow$ & ND & ND & ND & - & {$[67]$} \\
\hline \multicolumn{9}{|l|}{ PSEN1-R278I } \\
\hline Knock-in mice (heterozygous) & $\downarrow^{a}$ & $\rightarrow$ & $\rightarrow$ & $\rightarrow$ & $\rightarrow$ & $\rightarrow$ & APP-CTFs $\rightarrow$ & {$[68]$} \\
\hline Primary cells (from knock-in mice) & $\downarrow$ & $\rightarrow$ & $\uparrow$ & ND & $\rightarrow$ & ND & $\begin{array}{c}\text { Total } A \beta \rightarrow \\
\quad \mathrm{A} \beta 43 \uparrow\end{array}$ & {$[68]$} \\
\hline Kinetic in vitro assay & $\downarrow$ & $\downarrow$ & ND & $\downarrow$ & ND & ND & Total $A \beta \downarrow$ & {$[68]$} \\
\hline \multicolumn{9}{|l|}{ PSEN1-A246E } \\
\hline Overexpression (PSEN-/-) & $\rightarrow$ & $\rightarrow$ & $\uparrow$ & $\downarrow$ & $\rightarrow$ & $\rightarrow$ & APP-CTFs $\rightarrow$ & {$[64,81]$} \\
\hline Transgenic mice & $\rightarrow$ & $\uparrow$ & $\uparrow$ & ND & ND & ND & - & [124] \\
\hline Primary cells & $\uparrow$ & $\uparrow$ & $\uparrow$ & ND & ND & ND & - & {$[70,125]$} \\
\hline \multicolumn{9}{|l|}{ PSEN1- $\Delta$ Exon 9} \\
\hline Overexpression (HEK293) & $\rightarrow$ & $\uparrow$ & $\uparrow$ & $\downarrow$ & $\downarrow$ & $\downarrow$ & - & {$[78-80]$} \\
\hline Overexpression (PSEN-/-) & $\downarrow$ & $\rightarrow$ & $\uparrow$ & $\downarrow$ & $\downarrow$ & $\downarrow$ & APP-CTFs $\uparrow$ & {$[64,81]$} \\
\hline Transgenic mice & $\rightarrow$ & $\uparrow$ & $\uparrow$ & ND & ND & ND & - & {$[124]$} \\
\hline \multicolumn{9}{|l|}{ PSEN1-G384A } \\
\hline Overexpression (HEK293, CHO) & $\downarrow \rightarrow$ & $\uparrow$ & $\uparrow$ & ND & ND & $\downarrow$ & - & {$[79,80,83]$} \\
\hline Overexpression (PSEN-/-) & $\downarrow \rightarrow$ & $\uparrow$ & $\uparrow$ & $\downarrow$ & $\downarrow$ & $\downarrow$ & APP-CTFs $\rightarrow$ & {$[64,75,107]$} \\
\hline Kinetic in vitro assay & $\downarrow$ & $\rightarrow \uparrow$ & $\uparrow$ & $\downarrow$ & ND & ND & Total $A \beta \downarrow$ & {$[82,83]$} \\
\hline \multicolumn{9}{|l|}{ PSEN1-C410Y } \\
\hline Overexpression (PSEN-/-) & $\downarrow$ & $\downarrow$ & $\uparrow$ & ND & $\downarrow$ & ND & APP-CTFs $\uparrow$ & {$[75,81,123]$} \\
\hline \multicolumn{9}{|l|}{ PSEN2-N141I } \\
\hline Overexpression (COS-1, N2a, CHO) & $\downarrow$ & $\uparrow$ & $\uparrow$ & ND & ND & ND & - & {$[83,126]$} \\
\hline Overexpression (PSEN-/-) & $\downarrow$ & $\uparrow$ & $\uparrow$ & $\downarrow$ & $\downarrow$ & $\downarrow$ & APP-CTFs $\rightarrow$ & {$[64,65]$} \\
\hline Kinetic in vitro assay & $\downarrow$ & $\uparrow$ & $\uparrow$ & ND & ND & ND & - & [83] \\
\hline Transgenic mice & $\downarrow$ & $\uparrow$ & $\uparrow$ & ND & ND & ND & - & {$[127,128]$} \\
\hline Primary cells & $\rightarrow \uparrow$ & $\uparrow$ & $\uparrow$ & ND & ND & ND & - & {$[70,125]$} \\
\hline
\end{tabular}

PSEN mutations were chosen based on their investigation in multiple independent studies and model systems. All phenotypes of the PSEN mutants are reported in comparison to WT PSEN1. Studies that did not include a WT PSEN control condition are not included in this table. Up arrows indicate increase; down arrows indicate decrease; right-pointing arrows indicate no change compared to WT PSEN. Two arrows next to each other indicates that two or more studies reported different results compared to WT PSEN. Increased APP-CTFs, which are the immediate substrates of $\gamma$-secretase, can be interpreted as a sign of reduced enzyme activity. N-cadherin processing by $\gamma$-secretase was assessed in the studies by Bentahir and colleagues [63], Marambaud and colleagues [78] and Saito and colleagues [67] in different ways. However, in all cases a decrease indicates reduced processing of $\mathrm{N}$-cadherin and diminished formation of the $\mathrm{N}$-cadherin intracellular domain. ${ }^{\mathrm{T}}$ The reduction in endogenous mouse $A \beta 40$ steady-state levels in brain of heterozygous knock-in mice for the PSEN1-R278I mutation was only observed in the guanidine-HCL but not in the Tris-HCL-buffered saline soluble fraction. $A \beta$, amyloid- $\beta$; $A I C D$, amyloid precursor protein intracellular domain; $A P P$, amyloid precursor protein; $C H O$, $C$ hinese hamster ovary; CTF, carboxy-terminal fragment; ND, not determined; NICD, NOTCH intracellular domain; PSEN, presenilin; WT, wild type. 
sequentially every three to four amino acids along the $\alpha$ helical surface of the substrate APP, thereby converting longer $A \beta$ peptides into shorter species $[2,50]$. In this model, FAD PSEN mutations may cause an overall reduction in proteolytic activity of $\gamma$-secretase, and such less efficient, slower mutants may release more $A \beta 42$ molecules from the active center before further trimming of $A \beta 42$ to shorter $A \beta$ peptides. This model also appears to be supported by the fact that the 180 different PSEN1 mutations are scattered over the entire molecule without any apparent hot spots, which is most compatible with the loss-of-function hypothesis.

A small number of knock-in mouse strains for FAD PSEN1 mutations have been created, in which the mutant alleles are expressed under control of the endogenous mouse PSEN1 promoter [66-69,84]. These studies have either not provided evidence for substantially diminished $\gamma$-secretase activity (PSEN1-P264L, PSEN1-R278I) $[66,68]$ or have produced inconclusive results (PSEN1-I213T) $[67,84]$. The PSEN1-R278I mutation has been particularly well studied in knock-in mice [68] (Table 2). Homozygous knock-in mice for this mutation (R278I/R278I) were embryonic lethal and displayed a phenotype similar to $\mathrm{NOTCH}$ knockout mice. In the brain of these mice, accumulation of APP and N-cadherin CTFs was observed, and AICD and NICD fragments were undetectable. This was confirmed in kinetic in vitro studies using solubilized membrane preparations from heterozygous (WT/R278I) or homozygous knock-in mice, which showed reduced $A \beta$ and AICD generation from recombinant APP-CTF substrates in a gene-dosedependent manner. Taken together, these findings indicate a substantial loss of $\gamma$-secretase activity of the mutant allele [68]. The decrease in enzymatic activity of the PSEN1-R278I mutant appeared to be particularly severe as other PSEN1 mutations have not caused embryonic lethality in homozygous knock-in mice or were able to rescue the phenotype in PSEN1-/- knockout mice $[66,67,69,85,86]$. Importantly, no developmental defects were observed in heterozygous knock-in mice, and the brain morphology of 3- to 24-month-old mice was indistinguishable from that of WT mice. In brain tissue from heterozygous knock-in mice, no changes in the steady-state levels of APP and N-cadherin CTFs, AICD and NICD were observed, indicating that the $\gamma$-secretase-mediated release of intracellular domains is not affected by heterozygous expression of the PSEN1R278I mutation [68]. A slight decrease in endogenous mouse $A \beta 40$ was detected when brain tissue of 3 -monthold heterozygous mice was extracted in guanidine-HCL, but not when these mice were crossed to APP-transgenic mice. Very similar results have been reported for PSEN1M146V knock-in mice [69]. Interestingly, in APP/PSEN1R278I double transgenic mice, increased brain levels of
$A \beta 43$ were detected that correlated with enhanced amyloid pathology and cognitive deficits, and $A \beta 43$ appeared to induce the formation of Thioflavin T-positive aggregates in vitro even more efficiently than A $\beta 42$ [68]. This suggests that $A \beta 43$ might be an overlooked $A \beta$ species that contributes to the formation of neurotoxic $\mathrm{A} \beta$ oligomers and plaque pathology. However, it remains to be seen whether other PSEN mutations have any significant effects on the generation and secretion of A $\beta 43$. In summary, in vitro studies have provided conclusive evidence that many PSEN mutations cause a substantial loss of $\gamma$-secretase activity. However, the results from knock-in mice with heterozygous expression of PSEN mutants indicate that these frequently used cellular assays and, in particular, kinetic in vitro assays of PSEN mutants might underestimate the enzymatic activity of $\gamma$-secretase in a cellular context where both WT and mutant PSEN alleles contribute to the expressed $\gamma$-secretase complexes [66-69]. Importantly, in humans, validated loss-of-function mutations in the genes encoding NOTCH or the $\gamma$-secretase subunits PEN-2, PSEN1 and Nicastrin cause skin phenotypes ranging from acne inversa to cutaneous squamous cell carcinomas, as well as chronic myelomonocytic leukaemia [87-89]. In addition, genetic deletion of $\gamma$-secretase complex components in mice has demonstrated that a $30 \%$ reduction in $\gamma$-secretase activity is sufficient to induce a myeloproliferative disease resembling chronic myelomonocytic leukaemia [90]. However, these phenotypes, likely provoked by reduced $\mathrm{NOTCH}$ processing and signaling, have never been associated with FAD, further arguing that heterozygous expression of PSEN mutations does not result in a substantial loss of $\gamma$-secretase activity [4].

In addition, it has been proposed that FAD PSEN1 mutations impair $\gamma$-secretase-independent functions of PSEN proteins in signal transduction, autophagy and calcium homeostasis. The anti-apoptotic phosphatidylinositol 3-kinase-AKT signaling pathway seems to be positively regulated by PSEN proteins. PSEN deficiency or expression of PSEN1 FAD mutants reduced AKT phosphorylation and activity, and increased activity of its downstream target glycogen synthase kinase-3 (GSK-3) [91,92]. In knock-in mice for the PSEN1-I213T mutation, activation of GSK-3 $\beta$ was observed and correlated with increased phosphorylation of its substrate Tau and the formation of intracellular Tau inclusions [93]. Absence of PSEN or expression of PSEN1 FAD mutants has further been demonstrated to impair intracellular protein degradation, caused by a reduced turnover of autophagic vacuoles that fail to become acidified and fuse with lysosomes [60]. Another consistent observation has been that the induced release of calcium from endoplasmic reticulum stores is strongly increased by PSEN FAD 
mutants, which might result in deregulation of synaptic transmission and plasticity [61]. A few studies using primary cells from FAD carriers have confirmed that PSEN mutants negatively affect the role of PSEN in autophagic protein degradation and calcium homeostasis $[60,61]$. With respect to all of these proposed $\gamma$-secretaseindependent functions, FAD PSEN mutants mimic the phenotype of PSEN deficiency, indicating that the mutants behave as true loss-of-function alleles. While it is certain that PSEN mutants drive amyloidosis in FAD patients, however, the contribution of a potential loss of $\gamma$-secretase-independent functions to the clinical phenotype of FAD patients remains to be proven.

\section{Effects of PSEN mutations on small molecules targeting the $\boldsymbol{\gamma}$-secretase complex}

While investigations of FAD cases have provided invaluable insights into the pathogenesis of $\mathrm{AD}$, patients with FAD further constitute a unique population to conduct treatment or prevention trials with novel pharmaceuticals. Consequently, international consortia aim to recruit FAD patients with PSEN mutations for future clinical trials. In the past, pharmaceutical companies have been cautious to include FAD patients in clinical trials with the argument that novel therapeutics might be less efficacious in these patients because of their specific genetic background or their more aggressive disease course. The described effects of PSEN mutations on small molecules targeting the $\gamma$-secretase complex, which constitutes a principal drug target in $\mathrm{AD}$, have provided some support for this caution. Initially, it was described that the efficacy of $\gamma$-secretase inhibitors to decrease $A \beta$ production was reduced in cultured cells overexpressing PSEN mutants [94-96]. Similarly, it was demonstrated that PSEN but not APP mutants blocked the effects of $\gamma$-secretase modulators (GSMs), which preferentially reduce the amyloidogenic $A \beta 42$ species but spare proteolytic processing of the $\gamma$-secretase substrate NOTCH [94,97-100]. The initial studies used GSMs with low in vitro potency, which also did not have central nervous system drug properties. Recently, data have been reported for a second generation of potent and clinically relevant GSMs. The overall interpretation of these studies is more complex, with one report showing that PSEN mutants reduced the ability of GSMs to lower A $\beta 42$ irrespective of potency and structural class, and a second study claiming that only few particularly aggressive PSEN mutants rendered cells resistant to these GSMs [97,101]. It is important to note that all these results were obtained in cellular or animal models with overexpression of PSEN mutants. It remains possible, therefore, that the attenuating effect of PSEN mutants might not occur or be negligible when the mutation is expressed in the presence of one WT allele in FAD patients.

\section{A better understanding of presenilin mutations will require improved cellular models}

The lack of consensus concerning the effects of PSEN FAD mutations on $\gamma$-secretase-dependent and -independent functions and the heterogeneity of results obtained for individual mutations clearly demonstrate that a better understanding of FAD PSEN mutations will require improved cellular models. These models need to account for the heterozygous expression of PSEN mutants in the presence of one WT allele in FAD patients, and they should allow a rigorous comparison of the effects of a larger panel of mutations in a controlled system. Primary fibroblasts or induced pluripotent stem cells derived from human PSEN mutation carriers theoretically provide a suitable cellular model to study the effects of PSEN mutations [102]; however, this approach has serious drawbacks. First, public cell line repositories do not contain primary cells with a sufficient number of different PSEN mutations, and it is at present virtually impossible to acquire cells for specific mutations. Second, a general problem is the lack of genetically matched control cell lines. Commonly, cell lines derived from healthy donors are used as controls, which, because of differences in genetic background and cell derivation, display considerable biological variability. This concern could be addressed in the future through novel methods of genome editing, such as engineered zinc finger nucleases that might allow the generation of isogenic control cell lines [103]. However, these methods are not yet efficient enough to produce adequate numbers of mutant cell lines. Third, even if genetically matched control cells are available, the biological variability between mutant cell lines derived from donors with different PSEN FAD mutations makes them likely unsuitable for stringently controlled biochemical experiments. However, a clear alternative to human patient-derived cell lines are mouse embryonic stem cells, which are more easily amendable to genome editing using sitespecific recombinases [104]. Evidently, to establish improved models that faithfully reproduce the genetic and biochemical characteristics of PSEN FAD patients will be laborious and time-consuming, but it is clearly required to overcome the shortcomings of current models based on overexpression of PSEN mutants.

\section{Conclusion}

APP and PSEN mutations cause FAD with autosomaldominant inheritance and early onset disease. FAD is clinically and neuropathologically largely indistinguishable from the sporadic forms of $\mathrm{AD}$, indicating that amyloidosis is a driving force in the etiology of both FAD and sporadic AD. Biochemical studies have shown that APP mutations either shift the generation of $A \beta$ peptides towards the highly amyloidogenic A $\beta 42$ isoform or 
enhance the aggregation propensity of the $A \beta$ peptides. No evidence has been found that these mutations impair the physiological function of APP. PSEN mutations also drive amyloidosis in FAD patients through changes in the $A \beta 42 / A \beta 40$ ratio. In addition, it has been proposed that PSEN mutations could impair other $\gamma$-secretasedependent and -independent functions of PSEN. It is important, however, to note that none of theses phenotypes have been comprehensively replicated in experimental models that bear relevance to the heterozygous genetic background of FAD patients with PSEN mutations. In the few studies that have used primary cells from FAD patients or heterozygous knock-in mice, only single or a small number of PSEN mutations were investigated. It appears premature, therefore, to conclude that loss-of function phenotypes like reduced $\mathrm{NOTCH}$ signaling that were reported in overexpression studies with FAD PSEN mutants are relevant to the clinical phenotype of FAD patients, or may even contribute to the pathology of sporadic AD.

\section{Abbreviations}

$A \beta$, amyloid- $\beta$; $A D$, Alzheimer's disease; $A I C D$, amyloid precursor protein intracellular domain; APP, amyloid precursor protein; CAA, cerebral amyloid angiopathy; CTF, carboxy-terminal fragment; FAD, familial Alzheimer's disease; GSM, $\gamma$-secretase modulator; HCHWA-D, hereditary cerebral hemorrhage with amyloidosis Dutch-type; NICD, NOTCH intracellular domain; PSEN, presenilin; TMD, transmembrane domain; WT, wild type.

\section{Competing interests}

DB is a full-time employee of Merck Serono SA. The authors declare no other competing interests

\section{Acknowledgements}

We thank Elisabeth Stein for drawing the figures. SW was supported by grants from the Alzheimer Forschung Initiative and the Competence Network Degenerative Dementias of the German Federal Ministry of Education (grant number $01 \mathrm{Gl}$ 1004B).

\section{Published: 30 March 2012}

\section{References}

1. Alzheimer Association: 2011 Alzheimer's disease facts and figures. Alzheimers Dement 2011, 7:208-244.

2. De Strooper B, Annaert W: Novel research horizons for presenilins and gamma-secretases in cell biology and disease. Annu Rev Cell Dev Biol 2010, 26:235-260.

3. Selkoe DJ: Alzheimer's disease: genes, proteins, and therapy. Physiol Rev 2001, 81:741-766.

4. Bateman RJ, Aisen PS, De Strooper B, Fox NC, Lemere CA, Ringman JM, Salloway S, Sperling RA, Windisch M, Xiong C: Autosomal-dominant Alzheimer's disease: a review and proposal for the prevention of Alzheimer's disease. Alzheimers Res Ther 2011, 2:35.

5. Glenner GG, Wong CW: Alzheimer's disease: initial report of the purification and characterization of a novel cerebrovascular amyloid protein. Biochem Biophys Res Commun 1984, 120:885-890.

6. Kang J, Lemaire HG, Unterbeck A, Salbaum JM, Masters CL, Grzeschik KH, Multhaup G, Beyreuther K, Muller-Hill B: The precursor of Alzheimer's disease amyloid A4 protein resembles a cell-surface receptor. Nature 1987, 325:733-736.

7. Masters CL, Simms G, Weinman NA, Multhaup G, McDonald BL, Beyreuther K: Amyloid plaque core protein in Alzheimer disease and Down syndrome. Proc Natl Acad Sci U S A 1985, 82:4245-4249.

8. St George-Hyslop PH, Tanzi RE, Polinsky RJ, Haines JL, Nee L, Watkins PC, Myers RH, Feldman RG, Pollen D, Drachman D: The genetic defect causing familial Alzheimer's disease maps on chromosome 21. Science 1987 235:885-890

9. Tanzi RE, Gusella JF, Watkins PC, Bruns GA, St George-Hyslop P, Van Keuren ML, Patterson D, Pagan S, Kurnit DM, Neve RL: Amyloid beta protein gene: cDNA, mRNA distribution, and genetic linkage near the Alzheimer locus. Science 1987, 235:880-884.

10. Levy E, Carman MD, Fernandez-Madrid IJ, Power MD, Lieberburg I, van Duinen SG, Bots GT, Luyendijk W, Frangione B: Mutation of the Alzheimer's disease amyloid gene in hereditary cerebral hemorrhage, Dutch type. Science 1990, 248:1124-1126.

11. Goate A, Chartier-Harlin MC, Mullan M, Brown J, Crawford F, Fidani L, Giuffra L, Haynes A, Irving N, James L: Segregation of a missense mutation in the amyloid precursor protein gene with familial Alzheimer's disease. Nature 1991, 349:704-706.

12. Murrell J, Farlow M, Ghetti B, Benson MD: A mutation in the amyloid precursor protein associated with hereditary Alzheimer's disease. Science 1991, 254:97-99

13. Chartier-Harlin MC, Crawford F, Houlden H, Warren A, Hughes D, Fidani L, Goate A, Rossor M, Roques P, Hardy J: Early-onset Alzheimer's disease caused by mutations at codon 717 of the beta-amyloid precursor protein gene. Nature 1991, 353:844-846.

14. Haass C, Schlossmacher MG, Hung AY, Vigo-Pelfrey C, Mellon A, Ostaszewski BL, Lieberburg I, Koo EH, Schenk D, Teplow DB: Amyloid beta-peptide is produced by cultured cells during normal metabolism. Nature 1992, 359:322-325.

15. Baumketner A, Krone MG, Shea JE: Role of the familial Dutch mutation E22Q in the folding and aggregation of the 15-28 fragment of the Alzheimer amyloid-beta protein. Proc Natl Acad Sci U S A 2008, 105:6027-6032.

16. Miravalle L, Tokuda T, Chiarle R, Giaccone G, Bugiani O, Tagliavini F, Frangione B, Ghiso J: Substitutions at codon 22 of Alzheimer's abeta peptide induce diverse conformational changes and apoptotic effects in human cerebral endothelial cells. J Biol Chem 2000, 275:27110-27116.

17. Grant MA, Lazo ND, Lomakin A, Condron MM, Arai H, Yamin G, Rigby AC, Teplow DB: Familial Alzheimer's disease mutations alter the stability of the amyloid beta-protein monomer folding nucleus. Proc Natl Acad Sci U SA 2007, 104:16522-16527.

18. Lazo ND, Grant MA, Condron MC, Rigby AC, Teplow DB: On the nucleation of amyloid beta-protein monomer folding. Protein Sci 2005, 14:1581-1596.

19. Davis J, Van Nostrand WE: Enhanced pathologic properties of Dutch-type mutant amyloid beta-protein. Proc Natl Acad Sci U S A 1996, 93:2996-3000.

20. Murakami K, Irie K, Morimoto A, Ohigashi H, Shindo M, Nagao M, Shimizu T, Shirasawa T: Neurotoxicity and physicochemical properties of Abeta mutant peptides from cerebral amyloid angiopathy: implication for the pathogenesis of cerebral amyloid angiopathy and Alzheimer's disease. J Biol Chem 2003, 278:46179-46187.

21. Morelli L, Llovera R, Gonzalez SA, Affranchino JL, Prelli F, Frangione B, Ghiso J, Castano EM: Differential degradation of amyloid beta genetic variants associated with hereditary dementia or stroke by insulin-degrading enzyme. J Biol Chem 2003, 278:23221-23226.

22. Herzig MC, Eisele YS, Staufenbiel M, Jucker M: E22Q-mutant Abeta peptide (AbetaDutch) increases vascular but reduces parenchymal Abeta deposition. Am J Pathol 2009, 174:722-726.

23. De Jonghe C, Zehr C, Yager D, Prada CM, Younkin S, Hendriks L, Van BC, Eckman CB: Flemish and Dutch mutations in amyloid beta precursor protein have different effects on amyloid beta secretion. Neurobiol Dis 1998, 5:281-286.

24. Haass C, Hung AY, Selkoe DJ, Teplow DB: Mutations associated with a locus for familial Alzheimer's disease result in alternative processing of amyloid beta-protein precursor. J Biol Chem 1994, 269:17741-17748.

25. Tian Y, Bassit B, Chau D, Li YM: An APP inhibitory domain containing the Flemish mutation residue modulates gamma-secretase activity for Abeta production. Nat Struct Mol Biol 2010, 17:151-158.

26. Nilsberth C, Westlind-Danielsson A, Eckman CB, Condron MM, Axelman K, Forsell C, Stenh C, Luthman J, Teplow DB, Younkin SG, Näslund J, Lannfelt L: The 'Arctic' APP mutation (E693G) causes Alzheimer's disease by enhanced Abeta protofibril formation. Nat Neurosci 2001, 4:887-893.

27. Tomiyama T, Nagata T, Shimada H, Teraoka R, Fukushima A, Kanemitsu H, Takuma H, Kuwano R, Imagawa M, Ataka S, Wada Y, Yoshioka E, Nishizaki T, Watanabe $Y$, Mori H: A new amyloid beta variant favoring oligomerization in Alzheimer's-type dementia. Ann Neurol 2008, 63:377-387. 
28. Basun H, Bogdanovic N, Ingelsson M, Almkvist O, Naslund J, Axelman K, Bird TD, Nochlin D, Schellenberg GD, Wahlund LO, Lannfelt L: Clinical and neuropathological features of the arctic APP gene mutation causing earlyonset Alzheimer disease. Arch Neurol 2008, 65:499-505.

29. Herzig MC, Winkler DT, Burgermeister P, Pfeifer M, Kohler E, Schmidt SD, Danner S, Abramowski D, Stürchler-Pierrat C, Bürki K, van Duinen SG, MaatSchieman ML, Staufenbiel M, Mathews PM, Jucker M: Abeta is targeted to the vasculature in a mouse model of hereditary cerebral hemorrhage with amyloidosis. Nat Neurosci 2004, 7:954-960.

30. Tomiyama T, Matsuyama S, Iso H, Umeda T, Takuma H, Ohnishi K, Ishibashi K, Teraoka R, Sakama N, Yamashita T, Nishitsuji K, Ito K, Shimada H, Lambert MP, Klein WL, Mori H: A mouse model of amyloid \{beta\} oligomers: their contribution to synaptic alteration, abnormal tau phosphorylation, glial activation, and neuronal loss in vivo. J Neurosci 2010, 30:4845-4856.

31. Inayathullah M, Teplow DB: Structural dynamics of the DeltaE22 (Osaka) familial Alzheimer's disease-linked amyloid beta-protein. Amyloid 2011, 18:98-107.

32. Ovchinnikova OY, Finder VH, Vodopivec I, Nitsch RM, Glockshuber R: The Osaka FAD mutation E22Delta leads to the formation of a previously unknown type of amyloid beta fibrils and modulates Abeta neurotoxicity. J Mol Biol 2011, 408:780-791.

33. Cloe AL, Orgel JP, Sachleben JR, Tycko R, Meredith SC: The Japanese mutant Abeta (DeltaE22-Abeta(1-39)) forms fibrils instantaneously, with lowthioflavin T fluorescence: seeding of wild-type Abeta(1-40) into atypical fibrils by DeltaE22-Abeta(1-39). Biochemistry 2011, 50:2026-2039.

34. Van Nostrand WE, Melchor JP, Ruffini L: Pathologic amyloid beta-protein cell surface fibril assembly on cultured human cerebrovascular smooth muscle cells. J Neurochem 1998, 70:216-223.

35. Cai XD, Golde TE, Younkin SG: Release of excess amyloid beta protein from a mutant amyloid beta protein precursor. Science 1993, 259:514-516.

36. Citron M, Oltersdorf T, Haass C, McConlogue L, Hung AY, Seubert $P$, Vigo-Pelfrey C, Lieberburg I, Selkoe DJ: Mutation of the beta-amyloid precursor protein in familial Alzheimer's disease increases beta-protein production. Nature 1992, 360:672-674.

37. Citron M, Vigo-Pelfrey C, Teplow DB, Miller C, Schenk D, Johnston J, Winblad B, Venizelos N, Lannfelt L, Selkoe DJ: Excessive production of amyloid betaprotein by peripheral cells of symptomatic and presymptomatic patients carrying the Swedish familial Alzheimer disease mutation. Proc Natl Acad SciUS A 1994, 91:11993-11997.

38. Mullan M, Crawford F, Axelman K, Houlden H, Lilius L, Winblad B, Lannfelt L: A pathogenic mutation for probable Alzheimer's disease in the APP gene at the N-terminus of beta-amyloid. Nat Genet 1992, 1:345-347.

39. Lin X, Koelsch G, Wu S, Downs D, Dashti A, Tang J: Human aspartic protease memapsin 2 cleaves the beta-secretase site of beta-amyloid precursor protein. Proc Natl Acad Sci U S A 2000, 97:1456-1460.

40. Vassar R, Bennett BD, Babu-Khan S, Kahn S, Mendiaz EA, Denis P, Teplow DB, Ross S, Amarante P, Loeloff R, Luo Y, Fisher S, Fuller J, Edenson S, Lile J, Jarosinski MA, Biere AL, Curran E, Burgess T, Louis JC, Collins F, Treanor J, Rogers G, Citron M: Beta-secretase cleavage of Alzheimer's amyloid precursor protein by the transmembrane aspartic protease BACE. Science 1999, 286:735-741.

41. Koo EH, Squazzo SL: Evidence that production and release of amyloid beta-protein involves the endocytic pathway. J Biol Chem 1994 269:17386-17389

42. Haass C, Lemere CA, Capell A, Citron M, Seubert P, Schenk D, Lannfelt L, Selkoe DJ: The Swedish mutation causes early-onset Alzheimer's disease by beta-secretase cleavage within the secretory pathway. Nat Med 1995, 1:1291-1296

43. Hussain I, Hawkins J, Harrison D, Hille C, Wayne G, Cutler L, Buck T, Walter D, Demont E, Howes C, Naylor A, Jeffrey P, Gonzalez MI, Dingwall C, Michel A, Redshaw S, Davis JB: Oral administration of a potent and selective nonpeptidic BACE-1 inhibitor decreases beta-cleavage of amyloid precursor protein and amyloid-beta production in vivo. J Neurochem 2007, 100:802-809.

44. Atwal JK, Chen Y, Chiu C, Mortensen DL, Meilandt WJ, Liu Y, Heise CE, Hoyte K, LukW, Lu Y, Peng K, Wu P, Rouge L, Zhang Y, Lazarus RA, Scearce-Levie K, Wang W, Wu Y, Tessier-Lavigne M, Watts RJ: A therapeutic antibody targeting BACE1 inhibits amyloid-\{beta\} production in vivo. Sci Trans/ Med 2011, 3:84ra43.

45. Bergman A, Religa D, Karlstrom H, Laudon H, Winblad B, Lannfelt L, Lundkvist J, Naslund J: APP intracellular domain formation and unaltered signaling in the presence of familial Alzheimer's disease mutations. Exp Cell Res 2003 287:1-9.

46. Hecimovic S, Wang J, Dolios G, Martinez M, Wang R, Goate AM: Mutations in APP have independent effects on Abeta and CTFgamma generation. Neurobiol Dis 2004, 17:205-218.

47. Suzuki N, Cheung TT, Cai XD, Odaka A, Otvos L, Jr., Eckman C, Golde TE, Younkin SG: An increased percentage of long amyloid beta protein secreted by familial amyloid beta protein precursor (beta APP717) mutants. Science 1994, 264:1336-1340.

48. McGowan E, Pickford F, Kim J, Onstead L, Eriksen J, Yu C, Skipper L, Murphy MP, Beard J, Das P, Jansen K, Delucia M, Lin WL, Dolios G, Wang R, Eckman CB, Dickson DW, Hutton M, Hardy J, Golde T: Abeta42 is essential for parenchymal and vascular amyloid deposition in mice. Neuron 2005, 47:191-199.

49. GuY, Misonou H, Sato T, Dohmae N, Takio K, Ihara Y: Distinct intramembrane cleavage of the beta-amyloid precursor protein family resembling gamma-secretase-like cleavage of Notch. J Biol Chem 2001, 276:35235-35238.

50. Takami M, Nagashima Y, Sano Y, Ishihara S, Morishima-Kawashima M, Funamoto S, Ihara Y: \{gamma\}-Secretase: successive tripeptide and tetrapeptide release from the transmembrane domain of \{beta\}-carboxyl terminal fragment. J Neurosci 2009, 29:13042-13052.

51. Lichtenthaler SF, Wang R, Grimm H, Uljon SN, Masters CL, Beyreuther K: Mechanism of the cleavage specificity of Alzheimer's disease gammasecretase identified by phenylalanine-scanning mutagenesis of the transmembrane domain of the amyloid precursor protein. Proc Nat/ Acad SciUS A 1999, 96:3053-3058.

52. Sherrington R, Rogaev EI, Liang Y, Rogaeva EA, Levesque G, Ikeda M, Chi H, Lin C, Li G, Holman K, Tsuda T, Mar L, Foncin JF, Bruni AC, Montesi MP, Sorbi S, Rainero I, Pinessi L, Nee L, Chumakov I, Pollen D, Brookes A, Sanseau P, Polinsky RJ, Wasco W, Da Silva HA, Haines JL, Perkicak-Vance MA, Tanzi RE, Roses $A D$, et al: Cloning of a gene bearing missense mutations in earlyonset familial Alzheimer's disease. Nature 1995, 375:754-760.

53. Levylahad E, Wasco W, Poorkaj P, Romano DM, Oshima J, Pettingell WH, Yu CE, Jondro PD, Schmidt SD, Wang K, et al.: Candidate gene for the chromosome 1 familial Alzheimer's disease locus. Science 1995, 269:973-977.

54. Rogaev El, Sherrington R, Rogaeva EA, Levesque G, Ikeda M, Liang Y, Chi H, Lin C, Holman K, Tsuda T, et al:: Familial Alzheimer's disease in kindreds with missense mutations in a gene on chromosome 1 related to the Alzheimer's disease type 3 gene. Nature 1995, 376:775-778.

55. Alzheimer Disease and Frontotemporal Dementia Mutation Database [http://www.molgen.ua.ac.be/ADMutations]

56. Alzheimer Research Forum: The Presenilin-1 Mutations [http://www alzforum.org/res/com/mut/pre/table1.asp]

57. Bai G, Chivatakarn O, Bonanomi D, Lettieri K, Franco L, Xia C, Stein E, Ma L, Lewcock JW, Pfaff SL: Presenilin-dependent receptor processing is required for axon guidance. Cell 2011, 144:106-118.

58. Sardi SP, Murtie J, Koirala S, Patten BA, Corfas G: Presenilin-dependent ErbB4 nuclear signaling regulates the timing of astrogenesis in the developing brain. Cell 2006, 127:185-197.

59. Esselens $C$, Oorschot V , Baert V, Raemaekers T, Spittaels K, Serneels L, Zheng H, Saftig P, De Strooper B, Klumperman J, Annaert W: Presenilin 1 mediates the turnover of telencephalin in hippocampal neurons via an autophagic degradative pathway. J Cell Biol 2004, 166:1041-1054.

60. Lee JH, Yu WH, Kumar A, Lee S, Mohan PS, Peterhoff CM, Wolfe DM, Martinez Vicente M, Massey AC, Sovak G, Uchiyama Y, Westaway D, Cuervo AM, Nixon RA: Lysosomal proteolysis and autophagy require presenilin 1 and are disrupted by alzheimer-related PS1 mutations. Cell 2010, 141:1 146-1158

61. Mattson MP: ER calcium and Alzheimer's disease: in a state of flux. Sci Signal 2010, 3:pe10.

62. Parks AL, Curtis D: Presenilin diversifies its portfolio. Trends Genet 2007, 23:140-150.

63. Thinakaran G, Harris $\mathrm{CL}$, Ratovitski T, Davenport F, Slunt HH, Price DL, Borchelt DR, Sisodia SS: Evidence that levels of presenilins (PS1 and PS2) are coordinately regulated by competition for limiting cellular factors. $J$ Biol Chem 1997, 272:28415-28422

64. Bentahir M, Nyabi O, Verhamme J, Tolia A, Horre K, Wiltfang J, Esselmann H, De Strooper B: Presenilin clinical mutations can affect gamma-secretase activity by different mechanisms. J Neurochem 2006, 96:732-742.

65. Walker ES, Martinez M, Brunkan AL, Goate A: Presenilin 2 familial Alzheimer's disease mutations result in partial loss of function and dramatic changes 
in Abeta 42/40 ratios. J Neurochem 2005, 92:294-301.

66. Flood DG, Reaume AG, Dorfman KS, Lin YG, Lang DM, Trusko SP, Savage MJ, Annaert WG, De Strooper B, Siman R, Scott RW: FAD mutant PS-1 genetargeted mice: increased A beta 42 and $A$ beta deposition without APP overproduction. Neurobiol Aging 2002, 23:335-348.

67. Nakano Y, Kondoh G, Kudo T, Imaizumi K, Kato M, Miyazaki II, Tohyama M, Takeda J, Takeda M: Accumulation of murine amyloidbeta42 in a genedosage-dependent manner in PS1 'knock-in' mice. Eur J Neurosci 1999, 11:2577-2581.

68. Saito T, Suemoto T, Brouwers N, Sleegers K, Funamoto S, Mihira N, Matsuba Y, Yamada K, Nilsson P, Takano J, Nishimura M, I wata N, Van Broeckhoven C, Ihara Y, Saido TC: Potent amyloidogenicity and pathogenicity of Abeta43. Nat Neurosci 2011, 14:1023-1032.

69. Wang $\mathrm{R}$, Wang B, He W, Zheng H: Wild-type presenilin 1 protects against Alzheimer disease mutation-induced amyloid pathology. J Biol Chem 2006, 281:15330-15336.

70. Scheuner D, Eckman C, Jensen M, Song X, Citron M, Suzuki N, Bird TD, Hardy J, Hutton M, Kukull W, Larson E, Levy-Lahad E, Viitanen M, Peskind E, Poorkaj P, Schellenberg G, Tanzi R, Wasco W, Lannfelt L, Selkoe D, Younkin S: Secreted amyloid beta-protein similar to that in the senile plaques of Alzheimers disease is increased in vivo by the presenilin 1 and 2 and APP mutations linked to familial Alzheimers disease. Nat Med 1996, 2:864-869.

71. De Strooper B: Loss-of-function presenilin mutations in Alzheimer disease. Talking Point on the role of presenilin mutations in Alzheimer disease. EMBO Rep 2007, 8:141-146

72. Shen J, Kelleher RJ, 3rd: The presenilin hypothesis of Alzheimer's disease: Evidence for a loss-of-function pathogenic mechanism. Proc Natl Acad SCi USA 2007, 104:403-409.

73. Wolfe MS: When loss is gain: reduced presenilin proteolytic function leads to increased Abeta42/Abeta40. Talking Point on the role of presenilin mutations in Alzheimer disease. EMBO Rep 2007. 8:136-140.

74. Citron M, Westaway D, Xia W, Carlson G, Diehl T, Levesque G, Johnson-Wood K, Lee M, Seubert P, Davis A, Kholodenko D, Motter R, Sherrington R, Perry B, Yao H, Strome R, Lieberburg I, Rommens J, Kim S, Schenk D, Fraser P, St George Hyslop P, Selkoe DJ: Mutant presenilins of Alzheimer's disease increase production of 42- residue amyloid beta-protein in both transfected cells and transgenic mice. Nat Med 1997, 3:67-72.

75. Song W, Nadeau P, Yuan M, Yang X, Shen J, Yankner BA: Proteolytic release and nuclear translocation of Notch-1 are induced by presenilin-1 and impaired by pathogenic presenilin-1 mutations. Proc Natl Acad Sci U S A 1999, 96:6959-6963.

76. Baumeister R, Leimer U, Zweckbronner I, Jakubek C, Grunberg J, Haass C: Human presenilin-1, but not familial Alzheimer's disease (FAD) mutants, facilitate Caenorhabditis elegans Notch signalling independently of proteolytic processing. Genes Funct 1997, 1:149-159.

77. Levitan D, Doyle TG, Brousseau D, Lee MK, Thinakaran G, Slunt HH, Sisodia SS, Greenwald I: Assessment of normal and mutant human presenilin function in Caenorhabditis elegans. Proc Natl Acad Sci U S A 1996, 93:14940-14944.

78. Chen F, Gu Y, Hasegawa H, Ruan X, Arawaka S, Fraser P, Westaway D, Mount H, St George-Hyslop P: Presenilin 1 mutations activate gamma 42-secretase but reciprocally inhibit epsilon-secretase cleavage of amyloid precursor protein (APP) and S3-cleavage of notch. J Biol Chem 2002, 277:36521-36526.

79. Marambaud P, Wen PH, Dutt A, Shioi J, Takashima A, Siman R, Robakis NK: A CBP binding transcriptional repressor produced by the PS1/epsiloncleavage of N-cadherin is inhibited by PS1 FAD mutations. Cell 2003, 114:635-645

80. Moehlmann T, Winkler E, Xia X, Edbauer D, Murrell J, Capell A, Kaether C, Zheng H, Ghetti B, Haass C, Steiner H: Presenilin-1 mutations of leucine 166 equally affect the generation of the Notch and APP intracellular domains independent of their effect on Abeta 42 production. Proc Natl Acad Sci U S A 2002, 99:8025-8030

81. Nakajima M, Shimizu T, Shirasawa T: Notch-1 activation by familial Alzheimer's disease (FAD)-linked mutant forms of presenilin-1. J Neurosci Res 2000, 62:311-317.

82. Fluhrer R, Fukumori A, Martin L, Grammer G, Haug-Kröper M, Klier B, Winkler E, Kremmer E, Condron MM, Teplow DB, Steiner H, Haass C: Intramembrane proteolysis of GXGD-type aspartyl proteases is slowed by a familial Alzheimer disease-like mutation. J Biol Chem 2008, 283:30121-30128.

83. Qi Y, Morishima-Kawashima M, Sato T, Mitsumori R, Ihara Y: Distinct mechanisms by mutant presenilin 1 and 2 leading to increased intracellular levels of amyloid beta-protein 42 in Chinese hamster ovary cells. Biochemistry 2003, 42:1042-1052.

84. Shimojo M, Sahara N, Mizoroki T, Funamoto S, Morishima-Kawashima M, Kudo T, Takeda M, Ihara Y, Ichinose H, Takashima A: Enzymatic characteristics of 1213T mutant presenilin-1/gamma-secretase in cell models and knockin mouse brains: familial Alzheimer disease-linked mutation impairs gamma-site cleavage of amyloid precursor protein C-terminal fragment beta. J Biol Chem 2008, 283:16488-16496.

85. Davis JA, Naruse S, Chen H, Eckman C, Younkin S, Price DL, Borchelt DR, Sisodia SS, Wong PC: An Alzheimer's disease-linked PS1 variant rescues the developmental abnormalities of PS1-deficient embryos. Neuron 1998, 20:603-609.

86. Qian S, Jiang P, Guan XM, Singh G, Trumbauer ME, Yu H, Chen HY, Van de Ploeg $L H$, Zheng $H$ : Mutant human presenilin 1 protects presenilin 1 null mouse against embryonic lethality and elevates Abeta1-42/43 expression. Neuron 1998, 20:611-617.

87. Klinakis A, Lobry C, Abdel-Wahab O, Oh P, Haeno H, Buonamici S, van De Walle I, Cathelin S, Trimarchi T, Araldi E, Liu C, Ibrahim S, Beran M, Zavadil J, Efstratiadis A, Taghon T, Michor F, Levine RL, Aifantis I: A novel tumoursuppressor function for the Notch pathway in myeloid leukaemia. Nature 2011, 473:230-233

88. Wang B, Yang W, Wen W, Sun J, Su B, Liu B, Ma D, Lv D, Wen Y, Qu T, Chen M, Sun $M$, Shen $Y$, Zhang X: Gamma-secretase gene mutations in familial acne inversa. Science 2010, 330:1065.

89. Wang NJ, Sanborn Z, Arnett KL, Bayston L, Liao W, Proby CM, Leigh IM, Collisson EA, Gordon PB, Jakkula L, Pennypacker S, Zou Y, Sharma M, North JP, Vemula SS, Mauro TM, Neuhaus IM, Leboit PE, Hur JS, Park K, Huh N, Kwok PY, Arron ST, Massion PP, Bale AE, Haussler D, Cleaver JE, Gray JW, Spellman PT, South AP, et al: Loss-of-function mutations in Notch receptors in cutaneous and lung squamous cell carcinoma. Proc Natl Acad SciU S A 2011, 108:17761-17766.

90. Li T, Wen H, Brayton C, Laird FM, Ma G, Peng S, Placanica L, Wu TC, Crain BJ, Price DL, Eberhart CG, Wong PC: Moderate reduction of gamma-secretase attenuates amyloid burden and limits mechanism-based liabilities. J Neurosci 2007, 27:10849-10859.

91. Baki L, Neve RL, Shao Z, Shioi J, Georgakopoulos A, Robakis NK: Wild-type but not FAD mutant presenilin-1 prevents neuronal degeneration by promoting phosphatidylinositol 3-kinase neuroprotective signaling. J Neurosci 2008, 28:483-490.

92. Kang DE, Yoon IS, Repetto E, Busse T, Yermian N, le L, Koo EH: Presenilins mediate phosphatidylinositol 3-kinase/AKT and ERK activation via select signaling receptors. Selectivity of PS2 in platelet-derived growth factor signaling. J Biol Chem 2005, 280:31537-31547.

93. Tanemura K, Chui DH, Fukuda T, Murayama M, Park JM, Akagi T, Tatebayashi Y, Miyasaka T, Kimura T, Hashikawa T, Nakano Y, Kudo T, Takeda M, Takashima A: Formation of tau inclusions in knock-in mice with familial Alzheimer disease (FAD) mutation of presenilin 1 (PS1). J Biol Chem 2006, 281:5037-5041.

94. Czirr E, Leuchtenberger S, Dorner-Ciossek C, Schneider A, Jucker M, Koo EH, Pietrzik CU, Baumann K, Weggen S: Insensitivity to Abeta 42-lowering nonsteroidal anti-inflammatory drugs (NSAIDs) and gamma-secretase inhibitors is common among aggressive presenilin-1 mutations. J Biol Chem 2007, 282:24504-24513.

95. Ikeuchi T, Dolios G, Kim SH, Wang R, Sisodia SS: Familial Alzheimer diseaselinked presenilin 1 variants enhance production of both Abeta 1-40 and Abeta 1-42 peptides that are only partially sensitive to a potent aspartyl protease transition state inhibitor of "gamma-secretase". J Biol Chem 2003, 278:7010-7018.

96. Xia W, Ostaszewski BL, Kimberly WT, Rahmati T, Moore CL, Wolfe MS, Selkoe DJ: FAD mutations in presenilin-1 or amyloid precursor protein decrease the efficacy of a gamma-secretase inhibitor: evidence for direct involvement of PS1 in the gamma-secretase cleavage complex. Neurobiol Dis 2000, 7:673-681.

97. Hahn S, Bruning T, Ness J, Czirr E, Baches S, Gijsen H, Korth C, Pietrzik CU, Bulic $B$, Weggen S: Presenilin-1 but not amyloid precursor protein mutations present in mouse models of Alzheimer's disease attenuate the response of cultured cells to gamma-secretase modulators regardless of their potency and structure. J Neurochem 2011, 116:385-395.

98. Page RM, Baumann K, Tomioka M, Perez-Revuelta BI, Fukumori A, Jacobsen $H_{\text {, }}$ Flohr A, Luebbers T, Ozmen L, Steiner H, Haass C: Generation of Abeta 38 and Abeta 42 is independently and differentially affected by FADassociated presenilin 1 mutations and gamma -secretase modulation. 
J Biol Chem 2008, 283:677-683.

99. Page RM, Gutsmiedl A, Fukumori A, Winkler E, Haass C, Steiner H: APP mutants respond to \{gamma\}-secretase modulators. J Biol Chem 2010, 285:17798-17810

100. Weggen S, Eriksen JL, Sagi SA, Pietrzik CU, Ozols V, Fauq A, Golde TE, Koo EH: Evidence that nonsteroidal anti-inflammatory drugs decrease amyloid beta 42 production by direct modulation of gamma-secretase activity. J Biol Chem 2003, 278:31831-31837.

101. Kretner B, Fukumori A, Gutsmiedl A, Page RM, Luebbers T, Galley G, Baumann K, Haass C, Steiner H: Attenuated A\{́beta\}42 responses to low potency \{gamma\}-secretase modulators can be overcome for many pathogenic presenilin mutants by second-generation compounds. J Biol Chem 2011, 286:15240-15251

102. Dolmetsch R, Geschwind DH: The human brain in a dish: the promise of iPSC-derived neurons. Cell 2011, 145:831-834.

103. Soldner F, Laganière J, Cheng AW, Hockemeyer D, Gao Q, Alagappan R, Khurana V, Golbe LI, Myers RH, Lindquist S, Zhang L, Guschin D, Fong LK, Vu BJ, Meng X, Urnov FD, Rebar EJ, Gregory PD, Zhang HS, Jaenisch R: Generation of isogenic pluripotent stem cells differing exclusively at two early onset parkinson point mutations. Cell 2011, 146:318-331.

104. Turan S, Galla M, Ernst E, Qiao J, Voelkel C, Schiedlmeier B, Zehe C, Bode J: Recombinase-mediated cassette exchange (RMCE): traditional concepts and current challenges. J Mol Biol 2011, 407:193-221.

105. Di Fede G, Catania M, Morbin M, Rossi G, Suardi S, Mazzoleni G, Merlin M, Giovagnoli AR, Prioni S, Erbetta A, Falcone C, Gobbi M, Colombo L, Bastone A, Beeg M, Manzoni C, Francescucci B, Spagnoli A, Cantù L, Del Favero E, Levy E, Salmona $\mathrm{M}$, Tagliavini $\mathrm{F}$ : A recessive mutation in the APP gene with dominant-negative effect on amyloidogenesis. Science 2009, 323:1473-1477.

106. Janssen JC, Beck JA, Campbell TA, Dickinson A, Fox NC, Harvey RJ, Houlden H, Rossor MN, Collinge J: Early onset familial Alzheimer's disease: Mutation frequency in 31 families. Neurology 2003, 60:235-239.

107. Wakutani Y, Watanabe K, Adachi Y, Wada-Isoe K, Urakami K, Ninomiya H, Saido TC, Hashimoto T, Iwatsubo T, Nakashima K: Novel amyloid precursor protein gene missense mutation (D678N) in probable familial Alzheimer's disease. J Neurol Neurosurg Psychiatry 2004, 75:1039-1042.

108. Hendriks L, van Duijn CM, Cras P, Cruts M, Van HW, van HF, Warren A, McInnis $M G$, Antonarakis SE, Martin JJ: Presenile dementia and cerebral haemorrhage linked to a mutation at codon 692 of the beta-amyloid precursor protein gene. Nat Genet 1992, 1:218-221.

109. Bugiani O, Giaccone G, Rossi G, Mangieri M, Capobianco R, Morbin M, Mazzoleni G, Cupidi C, Marcon G, Giovagnoli A, Bizzi A, Di Fede G, Puoti G, Carella F, Salmaggi A, Romorini A, Patruno GM, Magoni M, Padovani A, Tagliavini F: Hereditary cerebral hemorrhage with amyloidosis associated with the E693K mutation of APP. Arch Neurol 2010, 67:987-995.

110. Grabowski TJ, Cho HS, Vonsattel JP, Rebeck GW, Greenberg SM: Novel amyloid precursor protein mutation in an lowa family with dementia and severe cerebral amyloid angiopathy. Ann Neurol 2001, 49:697-705.

111. Rossi G, Giaccone G, Maletta R, Morbin M, Capobianco R, Mangieri M, Giovagnoli AR, Bizzi A, Tomaino C, Perri M, Di Natale M, Tagliavini F, Bugiani O, Bruni AC: A family with Alzheimer disease and strokes associated with A713T mutation of the APP gene. Neurology 2004, 63:910-912.

112. Kumar-Singh S, De Jonghe C, Cruts M, Kleinert R, Wang R, Mercken M, De Strooper B, Vanderstichele H, Löfgren A, Vanderhoeven I, Backhovens H, Vanmechelen E, Kroisel PM, Van Broeckhoven C: Nonfibrillar diffuse amyloid deposition due to a gamma(42)-secretase site mutation points to an essential role for $\mathrm{N}$-truncated A beta(42) in Alzheimer's disease. Hum Mol Genet 2000, 9:2589-2598.

113. Pasalar $P$, Najmabadi $H$, Noorian AR, Moghimi B, Jannati A, Soltanzadeh A, Krefft T, Crook R, Hardy J: An Iranian family with Alzheimer's disease caused by a novel APP mutation (Thr714Ala). Neurology 2002, 58:1574-1575.

114. Ancolio K, Dumanchin C, Barelli H, Warter JM, Brice A, Campion D, Frebourg T, Checler $\mathrm{F}$ : Unusual phenotypic alteration of beta amyloid precursor protein (betaAPP) maturation by a new Val-715 --> Met betaAPP-770 mutation responsible for probable early-onset Alzheimer's disease. Proc Natl Acad Sci U S A 1999, 96:4119-4124.

115. De Jonghe C, Esselens C, Kumar-Singh S, Craessaerts K, Serneels S, Checler F, Annaert W, Van BC, De SB: Pathogenic APP mutations near the gamma- secretase cleavage site differentially affect Abeta secretion and APP Cterminal fragment stability. Hum Mol Genet 2001, 10:1665-1671.

116. Eckman CB, Mehta ND, Crook R, Perez-tur J, Prihar G, Pfeiffer E, Graff-Radford $\mathrm{N}$, Hinder P, Yager D, Zenk B, Refolo LM, Prada CM, Younkin SG, Hutton M, Hardy J: A new pathogenic mutation in the APP gene (1716V) increases the relative proportion of A beta 42(43). Hum Mol Genet 1997, 6:2087-2089.

117. Guerreiro RJ, Baquero M, Blesa R, Boada M, Brás JM, Bullido MJ, Calado A, Crook R, Ferreira C, Frank A, Gómez-Isla T, Hernández I, Lleó A, Machado A, Martínez-Lage P, Masdeu J, Molina-Porcel L, Molinuevo JL, Pastor P, Pérez-Tur J, Relvas R, Oliveira CR, Ribeiro MH, Rogaeva E, Sa A, Samaranch L, SánchezValle R, Santana I, Tàrraga L, Valdivieso F, et al.: Genetic screening of Alzheimer's disease genes in Iberian and African samples yields nove mutations in presenilins and APP. Neurobiol Aging 2010, 31:725-731.

118. Murrell JR, Hake AM, Quaid KA, Farlow MR, Ghetti B: Early-onset Alzheimer disease caused by a new mutation (V717L) in the amyloid precursor protein gene. Arch Neurol 2000, 57:885-887.

119. Ghidoni R, Albertini V, Squitti R, Paterlini A, Bruno A, Bernardini S, Cassetta E, Rossini PM, Squitieri F, Benussi L, Binetti G: Novel T719P AbetaPP mutation unbalances the relative proportion of amyloid-beta peptides. $J$ Alzheimers Dis 2009, 18:295-303.

120. Kwok JB, Li QX, Hallupp M, Whyte S, Ames D, Beyreuther K, Masters CL, Schofield PR: Novel Leu723Pro amyloid precursor protein mutation increases amyloid beta42(43) peptide levels and induces apoptosis. Ann Neurol 2000, 47:249-253.

121. Theuns J, Marjaux E, Vandenbulcke M, Van Laere K, Kumar-Singh S, Bormans G, Brouwers N, Van den Broeck M, Vennekens K, Corsmit E, Cruts M, De Strooper B, Van Broeckhoven C, Vandenberghe R: Alzheimer dementia caused by a novel mutation located in the APP C-terminal intracytosolic fragment. Hum Mutat 2006, 27:888-896.

122. Tesco G, Ginestroni A, Hiltunen M, Kim M, Dolios G, Hyman BT, Wang R, Berezovska O, Tanzi RE: APP substitutions V715F and L720P alter PS1 conformation and differentially affect Abeta and AICD generation. J Neurochem 2005, 95:446-456.

123. Shimojo M, Sahara N, Murayama M, Ichinose H, Takashima A: Decreased Abeta secretion by cells expressing familial Alzheimer's disease-linked mutant presenilin 1. Neurosci Res 2007, 57:446-453.

124. Jankowsky LL, Fadale DJ, Anderson J, Xu GM, Gonzales V, Jenkins NA, Copeland NG, Lee MK, Younkin LH, Wagner SL, Younkin SG, Borchelt DR: Mutant presenilins specifically elevate the levels of the 42 residue betaamyloid peptide in vivo: evidence for augmentation of a 42-specific gamma secretase. Hum Mol Genet 2004, 13:159-170.

125. Qiang L, Fujita R, Yamashita T, Angulo S, Rhinn H, Rhee D, Doege C, Chau L, Aubry L, Vanti WB, Moreno H, Abeliovich A: Directed conversion of Alzheimer's disease patient skin fibroblasts into functional neurons. Cell 2011, 146:359-371

126. Tomita T, Maruyama K, Saido TC, Kume H, Shinozaki K, Tokuhiro S, Capell A, Walter J, Grünberg J, Haass C, Iwatsubo T, Obata K: The presenilin 2 mutation (N141I) linked to familial Alzheimer disease (Volga German families) increases the secretion of amyloid beta protein ending at the 42nd (or 43rd) residue. Proc Natl Acad Sci U S A 1997, 94:2025-2030.

127. Mastrangelo P, Mathews PM, Chishti MA, Schmidt SD, Gu Y, Yang J, Mazzella MJ, Coomaraswamy J, Horne P, Strome B, Pelly H, Levesque G, Ebeling C, Jiang Y, Nixon RA, Rozmahel R, Fraser PE, St George-Hyslop P, Carlson GA, Westaway $D$ : Dissociated phenotypes in presenilin transgenic mice define functionally distinct gamma-secretases. Proc Natl Acad Sci U S A 2005, 102:8972-8977.

128. Sawamura N, Morishima-Kawashima M, Waki H, Kobayashi K, Kuramochi T, Frosch MP, Ding K, Ito M, Kim TW, Tanzi RE, Oyama F, Tabira T, Ando S, Ihara Y: Mutant presenilin 2 transgenic mice. A large increase in the levels of Abeta 42 is presumably associated with the low density membrane domain that contains decreased levels of glycerophospholipids and sphingomyelin. J Biol Chem 2000, 275:27901-27908.

\section{doi:10.1186/alzrt107}

Cite this article as: Weggen S, Beher D: Molecular consequences of amyloid precursor protein and presenilin mutations causing autosomal-dominant Alzheimer's disease. Alzheimer's Research \& Therapy 2012, 4:9. 